\title{
Resistance to Change and Purchase Intention of Electric Vehicles: Empirical evidence from Vietnam
}

\author{
Nguyen Gia Ninh* \\ University of Finance-Marketing, Vietnam \\ *Corresponding author: guyenninh@ufm.edu.vn
}

\begin{abstract}
On the grounds that psychological factors are increasingly used to better explain the purchase intention of customers towards electric vehicles (EVs), this study aims to examine the critical but less explored roles of resistance to change and the need for uniqueness in the purchase intention of EVs besides other conventional factors such as perceived value or personal norms. In doing so, this study would help governments and managers introduce effective measures to persuade customers to change from traditional internal combustion engine vehicles (ICEVs) to EVs. Data was collected from 175 respondents in Vietnam and PLS-SEM was utilized to analyze the theoretical model. The results illustrate that resistance to change has a significant impact on the purchase intention of EVs. In addition, perceived value has the most significant effects on willingness to pay and purchase intention of EVs. The need for uniqueness also impacts purchase intention through the willingness to pay.
\end{abstract}

Keywords: Electric vehicles, Resistance to change, Need for uniqueness, Purchase intention, Asia, Vietnam. 


\section{Introduction}

Greenhouse gas emissions have been widely considered as an important reason leading to environmental degradation (e.g., National Assessment Synthesis Team, 2000). Though a wide variety of human activities could result in atmosphere pollutants, the transportation system has been well recognized as the main factor causing air pollution (e.g., Ju et al., 2019). A possible solution could be the exploitation of great benefits of electric vehicles (EVs) in reducing fuel consumption, decreasing exhaust gas emissions, and protecting the air (Shi et al., 2016; Hofmann et al., 2016). Indeed, a recent study by Liu et al. (2019) demonstrated that EVs can give rise to a 30-50\% decrease in carbon dioxide emission and a considerable reduction in fuel consumption compared with other internal combustion engine vehicles (ICEVs). Especially, in the light of the rapid development in battery technology, EVs are becoming less costly and more appealing to consumers (Scown et al., 2013).

The market for EVs in such developing Asian countries as Vietnam is highly promising. While the main means of transportation in Vietnam are still scooters, motorcycles, and electric motorbikes, Vietnam's economy continues growing steadily (WorldBank, 2021 b) providing Vietnamese with a good chance to possess prohibitively expensive means such as cars (Minh, 2020; Asean Securities, 2020). Indeed, the car market of Vietnam was the second-fastest developing market worldwide in 2016 and the sales of cars in 2020 witnessed a steady growth, stood at 296,634 cars, at 3.3\% higher than expected (BVSC, 2021; Dylan Pastoor, 2018). Nevertheless, a large number of motorcycles and ICEVs heavily contributed to traffic blockage, noise pollution, and air contamination, especially in such metropolitans as Hanoi and Ho Chi Minh City (Minh, 2020). In 2018, Hanoi was identified as one of the most polluted cities in Southeast Asia (IQAir, 2018). Similarly, Ho Chi Minh City also released a large amount of carbon dioxide, at 38.5 million tons each year (Minh, 2020).

As such, on the grounds that the Vietnamese car market is enormously fruitful, ICEVs are widespread and led to serious air contamination. Paradoxically, a feasible solution for air contamination, EVs (Liu et al., 2019), has not received enough attention from research and policy. Given underdeveloped infrastructure, limited incentive policies (Schröder and Iwasaki, 2021), and the effects of other negative factors, the sales of EVs in Vietnam has been surprisingly low (Thuy, 2021). This is the case for a large number of EV models ranging from iMIEV, Outlander PHEV, Taycan 4S, Turbo, Turbo S to Tesla 3 (Thuy, 2021). What is more, little research on the adoption of EVs was performed in such developing Asian countries as Vietnam to help facilitate EV adoption. Research on electric vehicles in Vietnam was normally conducted for electric motorcycles (Jones et al., 2013) and other electric two-wheeled vehicles (Thuy and Hong, 2019). To this end, more research on the purchase adoption of electric fourwheeled vehicles in developing Asian countries is required and this will in turn support the development of the EV market in such developing Asian countries (Tuyen, 2021).

Understanding the purchase intention of EVs of consumers is essential for both business and environmental reasons. This study would help to provide insights into the economical and psychological aspects that could facilitate the acceptance of EVs of customers, which in turn helps to increase purchase intention of EVs and ameliorate environmental issues. This study devotes rapt attention to human characteristics and personality traits such as resistance to change and the need for uniqueness and their 
effects on the purchase intention of EVs. Though past studies stressed the important roles of these psychological factors in purchase behavior of customers in some other industries such as online banking or beverage industries (Daniel, 1999; Munir, 2017), the relationships between these two psychological factors and the willingness to pay for EVs and purchase intention of EVs are rarely examined, providing a gap that needs to be filled in. These two psychological factors will be integrated into a Theory of planned behavior framework that includes attitude, personal norms, and perceived control to create a more complete theoretical framework and increase the predictive power of the theoretical model. In doing so, the significant effects of resistance to change and uniqueness on purchase intention for EVs will be examined. Subsequently, a more complete theoretical framework will be created to better explain the purchase intention of customers towards EVs.

\section{Theoretical Framework}

This study identifies and investigates the key antecedents driving the purchasing intention of EVs. There has been a wide range of theories used to explain purchasing intention and adoption of electric vehicles (EVs) such as consumption value theory (e.g., Han et al., 2017), rational choice theory (Zhang et al., 2011), or Theory of planned behavior (TPB) (e.g., Rezvani et al., 2015). Among these, TPB is one of the most commonly used theories to anticipate the intention to buy EVs of consumers. For example, Sang and Bekhet (2015) examined the TPB framework with a sample of car users in Malaysia and found that environmental concern, consumer knowledge, psychological benefit, and demographics significantly affect purchase intention for EVs. Similarly, Ng et al. (2018) also investigated the TPB framework with a sample of members of car communities in Hong Kong and found significant effects between most of the proposed factors. According to TPB, behavior is driven by the intention of a consumer to perform that action (Ajzen, 1991) and that intention is considered as a proxy of a specific behavior (Sheppard et al., 1988). In the transportation field, TPB is also utilized to predict a range of other driving behaviors such as drink and drive behaviors (e.g., Rivis et al., 2011).

The TPB approach suggested that an intention is decided by the attitude, subjective norm, and perceived control (Ajzen, 1991). The norm activation model is also incorporated into the TPB model with the role and direct effects of the personal norm to better explain pro-environmental behavior (Bamberg and Möser, 2007). Notably, the inclusion of other meaningful variables into the TPB model is also encouraged to increase the prediction power of the model (Ajzen, 1991; Sang and Bekhet, 2015). On the grounds that psychological factors, for example, the perceived performance of EVs (Nayum et al., 2016), personal innovativeness (He et al., 2018), or response efficacy (Ng et al., 2018), are increasingly used and help better explain the EV adoption, this study shifts the focus onto two salient psychological factors (i.e., resistance to change and need for uniqueness) which were added to complement the existing predictors of the model. What is more, attitudinal factors towards the environment including environmental concern and trust in EVs; personal norms; and perceived control consisting of willingness to pay and perceived value (Lai et al., 2015; $\mathrm{Ng}$ et al., 2018) were also incorporated into the theoretical model to create a more complete theoretical framework (Figure 1). 


\section{Willingness to Pay (WTP) and Purchase intention (PI)}

Purchase intention refers to a significant indicator of actual purchase behavior (Chang and Wildt, 1994). Purchase intention for EVs might be affected by a large number of factors ranging from charging infrastructure, EV design and features, to the willingness to pay (Kumar and Alok, 2020).

Specifically, an element of the TPB model is the perceived behavioral control relating to the perceived barriers or difficulty to conduct desired behaviors of individuals (Ajzen, 2005). These barriers are such situational constraints as opportunities or resources (Ajzen, 1991; Bamberg and Möser, 2007). On this ground, the willingness to pay a price was also used as a factor that might influence purchase decision of consumers in other industries in Vietnam, for instance, in higher education (Le et al., 2021).

Eco-friendly products are commonly regarded as being more costly than traditional products (Essoussi and Zahaf, 2008) and therefore, may be perceived as the main barrier to green product purchasing (Paul and Rana, 2012). Nonetheless, the price itself might not be a barrier to green purchasing once consumers are will to pay a premium price in exchange for more environmental benefits (Olson, 2013). Some recent empirical evidence also supported the positive link between willingness to pay and purchase intention of EVs (e.g., Moser, 2015). Thus, a hypothesis is proposed:

H1 The willingness to pay is positively related to the intention of consumers to purchase EVs

\section{Resistance to Change (RC)}

Resistance to change refers to the tendency of individuals to avoid making changes and underestimate changes in different contexts (Oreg, 2003). It can also be denoted as the tendency to resist the change from an existing vendor to other vendors (Kim and Gupta, 2012). Resistance to change could be explained by the status quo bias theory in which people prefer to sustain current situations or past decisions (Samuelson and Zeckhauser, 1988).

Resistance to change can be regarded as a unique characteristic of human beings and is normally used in other technology adoption (Quinn and Mueller, 1982). When a new technology is launched at large, it must satisfy a specific need of consumers that motivates consumers to adopt that new technology (Wallis Report, 1997). This resistance to change or the inertia of consumers was also found in banking industries when consumers hesitate to change from traditional ways of banking to online banking (Daniel, 1999). This resistance to change is able to affect the attitude of consumers towards online banking (Al-Somali et al., 2009). Regarding EVs, resistance to change could also influence the purchase intention of car drivers and would-be car drivers if they are prone to resist new changes in technologies and uncomfortable when thinking about how to learn very new and strange ways of operating and maintaining EVs or how to look for charging stations, together with the long time to charge the EVs (Rezvani et al., 2015). Other reasons for consumers' resistance could be the high costs of changing batteries and low EVs reselling prices (Bohnsack et al., 2014). 
From a relationship marketing perspective, car drivers can resist changing vendors due to the pre-established relationships with current vendors and therefore, customers can be willing to pay a premium for existing vendors (Bendapudi and Berry, 1997). In this case, resistance to change can happen due to both the monetary value and other services that customers can benefit from long-term vendors (Smith and Brynjolfsson, 2001). Past studies also found a significant relationship between the resistance to change and the willingness to pay more in Internet shopping (Kim and Gupta, 2012). As such, resistance to change is likely to affect the willingness to pay more for EVs due to their existing relationships with current vendors and the costs and inconvenience emerging from new changes. This can be the case for both car drivers and would-be car drivers because for those customers who are using petrol two-wheelers as scooters or motorcycles, the most popular means of transportation in Vietnam, a long-term relationship between them and scooter or motorcycle manufacturing firms can also exist. This relationship, together with the emerging costs and inconvenience resulting from using EVs instead of ICEVs, could impact their willingness to pay and purchase intention of EVs. Thus, two new hypotheses are proposed:

H2a The resistance to change is positively related to the willingness to pay of consumers for EVs.

H2b Resistance to change is positively related to the intention of consumers to purchase EVs.

\section{Need for Uniqueness (UNIQ)}

The need for uniqueness is an element of personality traits that could affect the attitude of consumers towards such innovations as online purchasing (Wu and Ke, 2015). Need for uniqueness refers to the trait of pursuing distinction in which people acquire, utilize, and arrange goods in such ways that could boost their social image and self-image (Tian et al., 2001). A desire for differentiation through using unusual products might affect product adoption (McAlister and Pessemier, 1982). The adoption of EVs in Vietnam is extremely low, suggesting the use of EVs can differentiate a consumer from the others (Tian et al., 2001). From this, consumers can become leaders, join in early user groups, and attract followers (Fisher and Price, 1992). In addition, almost all EVs models in Vietnam such as Tesla Model, Porche Taycan, Nissan Leaf, or VinFast VF e34 have nice designs that could make them recognizable and noticeable on the street. This could lead to a unique personal style (Belk, 1988) that is likely to facilitate uniqueness (Kron, 1983). Furthermore, EVs could also provide differentiation via their social and environmental value (Wei et al., 2020). With respect to the transportation industry, though research on the relationships between the need for uniqueness and purchase intention for cars is still limited, past research suggested that the need for uniqueness could have impact on the attitude of customers towards luxury cars (Bartikowski and Cleveland, 2017).

In addition, unique features of a brand could differentiate a brand from the others and lead to the preferences and willingness to pay more for that brand (Kalra and Goodstein, 1998). Empirical evidence also supported the significant positive relationships between the need for uniqueness and willingness to pay for such familiar brands as Coca-Cola, branded female clothes, Levi's jeans, or Reebok (Munir, 2017; Netemeyer et al., 2004). We argue that the unique features of EVs can differentiate EVs from other cars and could be able to boost car users' social image and self-image. This in turn can allow car users to pay more for a price premium. Thus, two hypotheses are proposed: 
H3a Need for uniqueness is positively related to the willingness to pay of consumers for EVs.

H3b Need for uniqueness is positively related to the intention of consumers to purchase EVs.

\section{Environmental Concern (EC)}

Environmental concern denotes the emotional reactions of consumers towards environmental issues such as aversion, sorrow, and compassion (Milfont and Gouveia, 2006). Environmental concern was found to be significantly associated with such consumer behaviors as recycling newspapers, buying environmentally friendly products, or helping pro-environmental groups (Kang and Park, 2011). In addition, individuals with environmental concern are more likely to buy hybrid electric vehicles (Kahn, 2007). Environmental concern is also an important factor affecting purchasing intention of EVs (Lai et al., 2015). Consumers who are concerned about the environment are inclined to pay a premium to receive more environmental benefits (Hansla et al., 2008). Thus, two hypotheses are proposed:

H4a The environmental concern of consumers is positively related to their willingness to pay more for EVs.

H4b The environmental concern of consumers is positively related to their intention to purchase EVs.

\section{Perceived Trust in EVs (PT)}

Consumers are more likely to purchase a green product when they believe in its ability to solve environmental issues. When they trust the effectiveness of a green product in resolving environmental problems, they are inclined to purchase that product (Lee et al., 2014). Hence, this trust in EVs is a significant antecedent of purchase intention (Bang et al., 2000). When customers receive more information about the usefulness of green products towards environmental protection, they are more likely to purchase these green products and be more willing to pay more for them (Bang et al., 2000). Hence, two hypotheses are proposed:

H5a The perceived trust in EVs of consumers is positively related to their willingness to pay for EVs.

H5b The perceived trust in EVs of consumers is positively related to their intention to purchase EVs.

\section{Personal Norms (PN)}

Personal norms are regarded as an extended factor of the TPB model and refer to the normative belief and moral commitment of an individual (Schwartz, 1977). Once the personal norms towards a behavior are activated, an individual feels a strong sense of moral obligation to perform that behavior, which in turn leads to behavioral intention (Schwartz, 1977). Empirical evidence also suggested that PN is positively associated with the intention to adopt EVs (Peters et al., 2011). Hence, a hypothesis is proposed:

H6 The personal norms are positively related to the intention of consumers to purchase EVs. 


\section{Perceived Value (PV)}

Customers are inclined to choose products based on their functional value (Sheth, 1983). Regarding EVs, functional values of EVs come from the utility, benefits, and practicality of EVs' functions and tangible features (Schuitema et al., 2013). Empirical evidence also illustrated the significant relationships between perceived value and purchase intention of EVs (Han et al., 2017). Consumers may also find that EVs can bring them benefits but they are reluctant to purchase because of such emerging costs as purchasing and maintaining costs. As a result, they are willing to pay a premium for EVs but this premium is not considerable (Zhao et al., 2018). Thus, two hypotheses are proposed:

H7a The perceived value is positively related to the willingness to pay of consumers for EVs.

H7b The perceived value is positively related to the intention of consumers to purchase EVs.

\section{Research Method}

\section{Participants}

A non-probability sampling technique with convenience sampling method was used for data collection (Malhotra, 2006) in which online questionnaires were sent to two automotive communities, otofun and otosaigon. These are two among the six most popular automotive forums in Vietnam where people can receive useful information about new car models and get credible advice about cars (Reviewxehoi360, 2019). We expect that the participants from these communities would have considerable knowledge of cars and electric cars and are potential consumers of EVs. A similar approach was also applied by past research (e.g., $\mathrm{Ng}$ et al., 2018). Besides, online questionnaires were also sent to those participants who are interested in this study. After removing six incomplete and inappropriate responses from a sample of 181 respondents, 175 responses were retained for further analyses. The sample comprised $52.6 \%$ male and $46.9 \%$ female (Table 1 ).

\section{Instrument and Measures}

Measures of determinants of purchase intention of EVs were adopted from related previous research (Table 2). Seven-point Likert's scales were utilized for measurement items and anchored by two points, 1 for strongly disagree and 7 for strongly agree.

\section{Data Analysis}

PLS-SEM was used for data analysis to strengthen the ability to process the complex model in this study (Sarstedt et al., 2017). The sample size of 175 is regarded as adequate for PLS-SEM in this study (Hair et al., 2011). SmartPLS 3.0 (Ringle et al., 2015) was used to calculate the parameters of SEM. 
Table 1: Profile of the Respondents

\begin{tabular}{llcc}
\hline Characteristic & Rank & Frequency & Percentage \\
\hline Gender & Male & 92 & $52.6 \%$ \\
& Female & 82 & $46.9 \%$ \\
& Not specified & 1 & $0.6 \%$ \\
Education level & Secondary school or below & 1 & $0.6 \%$ \\
& College & 6 & $3.4 \%$ \\
& University & 136 & $77.7 \%$ \\
Age & Postgraduate degree & 32 & $18.3 \%$ \\
& $18-24$ & 104 & $59.4 \%$ \\
& $25-34$ & 35 & $20 \%$ \\
& $35-44$ & 26 & $14.9 \%$ \\
Car Driving & $45-54$ & 9 & $5.1 \%$ \\
License & 55 or above & 1 & $0.6 \%$ \\
Purchasing & No & 56 & $32 \%$ \\
Experience & Yes & 119 & $68 \%$ \\
\hline
\end{tabular}

\section{Findings}

\section{Measurement Model}

Cronbach's alphas and composite reliabilities of all measures are above 0.7 (Table 2), suggesting good reliability and internal consistency of all measures (Nunnally, 1978). All average variance extracted (AVEs) are greater than 0.5 , and factor loadings are above 0.7 , indicating adequate convergent validity of the constructs (Hair et al., 2011).

Fornell-Larcker criterion evaluation was used to evaluate the discriminant validity of each construct (Table 3). All square roots of AVEs of constructs are greater than the correlations between them and any other constructs, supporting the discriminant validity of all constructs in the model (Fornell and Larcker, 1981). Next, heterotraitmonotrait ratio of correlations (HTMT), a criterion suggested by Henseler et al. (2015) was also applied. HTMT values ranged from 0.082 to 0.781 , signaling satisfactory discriminant validity regarding HTMT85 (Garson, 2016). 
Table 2: Evaluation of Measures

\begin{tabular}{|c|c|c|c|}
\hline Constructs and items (source) quality criteria & $\begin{array}{l}\text { Item } \\
\text { mean }\end{array}$ & SD & $\begin{array}{c}\text { Standardized } \\
\text { factor loadings }\end{array}$ \\
\hline \multicolumn{4}{|c|}{ Environmental Concern $($ Lee, 2009) $C A=0.893, C R=0.933, A V E=0.824}$. \\
\hline Vietnam's environment is my major concern & 6.07 & 1.165 & 0.897 \\
\hline $\begin{array}{l}\text { I am emotionally involved in environmental protection } \\
\text { issues in Vietnam }\end{array}$ & 6.13 & 1.184 & 0.940 \\
\hline $\begin{array}{l}\text { I often think about how the environmental quality in } \\
\text { Vietnam can be improved }\end{array}$ & 5.79 & 1.316 & 0.885 \\
\hline \multicolumn{4}{|c|}{ Trust to EV (Chen et al., 2015) $C A=0.925, C R=0.952, A V E=0.869$. } \\
\hline I believed in EVs' environmental image & 5.74 & 1.232 & 0.916 \\
\hline $\begin{array}{l}\text { I think EVs' environmental functionality is generally } \\
\text { dependable }\end{array}$ & 5.65 & 1.260 & 0.948 \\
\hline $\begin{array}{l}\text { Overall, I believe that EVs' environmental claims are } \\
\text { trustworthy }\end{array}$ & 5.55 & 1.262 & 0.933 \\
\hline \multicolumn{4}{|c|}{ Personal norm (Peters et al., 2011) $C A=0.849, C R=0.930, A V E=0.869$. } \\
\hline $\begin{array}{l}\text { No matter what other people do, I think it right to choose } \\
\text { a car with energy consumption that is as low as possible. }\end{array}$ & 6.00 & 1.199 & 0.932 \\
\hline $\begin{array}{l}\text { When making a trip by car, it should burden the climate } \\
\text { and energy consumption as little as possible. }\end{array}$ & 6.07 & 1.170 & 0.933 \\
\hline \multicolumn{4}{|c|}{ Perceived value of EV (Egbue and Long, 2012) $C A=0.833, C R=0.888, A V E=0.666$} \\
\hline EVs need less maintenance & 4.27 & 1.749 & 0.732 \\
\hline The style of EV is good & 4.71 & 1.519 & 0.767 \\
\hline An $\mathrm{EV}$ is more comfortable & 4.67 & 1.383 & 0.889 \\
\hline Overall, EVs deliver me good value & 4.94 & 1.372 & 0.866 \\
\hline \multicolumn{4}{|c|}{ Willingness to pay (Moser, 2015, Ng et al., 2018) $C A=0.881, C R=0.927, A V E=0.808$. } \\
\hline $\begin{array}{l}\text { I am willing to pay more for environmentally friendly } \\
\text { products }\end{array}$ & 5.48 & 1.462 & 0.880 \\
\hline I am willing to pay more to ride an electric vehicle & 4.93 & 1.515 & 0.887 \\
\hline $\begin{array}{l}\text { I am willing to pay more to purchase an environmentally } \\
\text { friendly EV }\end{array}$ & 5.19 & 1.472 & 0.929 \\
\hline \multicolumn{4}{|c|}{$\begin{array}{l}\text { Purchase Intention (Pavlou, 2003; Yang et al., 2016; Wang et al., 2016) } C A=0.926, C R= \\
0.944, A V E=0.773\end{array}$} \\
\hline Given the chance, I intend to buy an EV & 5.17 & 1.468 & 0.891 \\
\hline I recommend that others buy an EV & 4.99 & 1.484 & 0.889 \\
\hline If I replace my vehicle, I will consider an EV first & 4.82 & 1.550 & 0.896 \\
\hline $\begin{array}{l}\text { Given the chance, I predict that I should buy an EV in the } \\
\text { future. }\end{array}$ & 5.34 & 1.354 & 0.869 \\
\hline It is likely that I will buy an EV in the near future. & 4.94 & 1.508 & 0.848 \\
\hline \multicolumn{4}{|c|}{ Resistance to Change (Al-Somali et al., 2009) $C A=0.739, C R=0.843, A V E=0.641$} \\
\hline $\begin{array}{l}\text { I am interested to hear about new technological } \\
\text { developments }\end{array}$ & 6.04 & 1.210 & 0.808 \\
\hline Technological developments have enhanced our lives & 6.22 & 1.139 & 0.749 \\
\hline $\begin{array}{l}\text { I feel comfortable in changing and using EVs for my } \\
\text { transportation activities }\end{array}$ & 5.25 & 1.362 & 0.842 \\
\hline \multicolumn{4}{|c|}{ Need for uniqueness (Tian et al., 2001) $C A=0.870, C R=0.920, A V E=0.793$} \\
\hline $\begin{array}{l}\text { When a product I own becomes popular among the } \\
\text { general population, I begin to use it less. }\end{array}$ & 4.22 & 1.869 & 0.891 \\
\hline $\begin{array}{l}\text { I often try to avoid products or brands that I know are } \\
\text { bought by the general population. }\end{array}$ & 3.89 & 2.024 & 0.909 \\
\hline $\begin{array}{l}\text { Products don't seem to hold much value for me when they } \\
\text { are purchased regularly by everyone }\end{array}$ & 3.47 & 1.98 & 0.870 \\
\hline
\end{tabular}


Table 3: Fornell-Larcker Criterion Assessment

\begin{tabular}{lcccccccc}
\hline & EC & PI & PN & PV & RC & PT & UNIQ & WTP \\
\hline EC & $\mathbf{0 . 9 0 8}$ & & & & & & & \\
PI & 0.398 & $\mathbf{0 . 8 7 9}$ & & & & & & \\
PN & 0.590 & 0.387 & $\mathbf{0 . 9 3 2}$ & & & & & \\
PV & 0.417 & 0.701 & 0.466 & $\mathbf{0 . 8 1 6}$ & & & & \\
RC & 0.485 & 0.599 & 0.540 & 0.606 & $\mathbf{0 . 8 0 1}$ & & & \\
PT & 0.487 & 0.540 & 0.552 & 0.508 & 0.529 & $\mathbf{0 . 9 3 2}$ & & \\
UNIQ & 0.173 & 0.427 & 0.059 & 0.470 & 0.296 & 0.238 & $\mathbf{0 . 8 9 1}$ & \\
WTP & 0.465 & 0.598 & 0.437 & 0.591 & 0.553 & 0.480 & 0.368 & $\mathbf{0 . 8 9 9}$ \\
\hline
\end{tabular}

\section{Structural Model}

All variance inflation factors (VIFs) ranged from 1.365 to 2.207 , well below the cutoff point value of 5 (Hair et al., 2011), indicating that collinearity was not a problem in this model. Second, $R^{2}$ values of endogenous constructs, willingness to pay and purchase intention, are at 0.459 and 0.595 (Table 4), correspondingly, suggesting substantive predictive power of these two endogenous variables (Cohen, 1988). Next, the effect sizes of independent variables on dependent variables ranged from 0.02 to 0.16 (Table 4), demonstrating the small-to-medium effects of exogenous constructs on endogenous constructs. Furthermore, $Q^{2}$ values, the predictive accuracy of the model, are above zero (Table 4) for both dependent constructs and are all acceptable (Hair et al., 2014).

Bootstrapping was performed with 5,000 samples to examine the significance of path coefficients (Table 4). Perceived value has the strongest effect on purchase intention ( $b=0.38, p<.001$ ), in supporting of H7b. Resistance to change, willingness to pay, and perceived trust have significant effects on purchase intention, supporting $\mathrm{H} 2 \mathrm{~b}, \mathrm{H} 1$, and H5b, with $b=0.18, p<.05 ; b=0.18, p<.05$, and $b=0.18, p<.05$, respectively. Nonetheless, the direct effects of environmental concern (H4b), personal norms (H6), and need for uniqueness $(\mathrm{H} 3 \mathrm{~b})$ on purchase intention were not supported. In a similar vein, perceived value has the strongest effect on willingness to pay $(b=0.27, p<.001)$, supporting H7a. Resistance to change also and need for uniqueness have significant effect on willingness to pay with $b=0.19, p<.05$ and $b=0.13, p<.05$, respectively, supporting $\mathrm{H} 2 \mathrm{a}$ and $\mathrm{H} 3 \mathrm{a}$. Nevertheless, the direct effects of environmental concern (H4a) and perceived trust (H5a) on willingness to pay were not supported.

\section{Robustness Check}

To further confirm these mediating effects, SPSS Macro PROCESS (Preacher and Hayes, 2008) was also utilized. Regarding the impact of resistance to change on purchase intention, the indirect effect through the willingness to pay was significant ( $b=0.22, p=0.048<0.05 ; \mathrm{CI}[0.13,0.32])$ and the direct effect of resistance to change on purchase intention was significant $(b=0.44, p=0.000<0.001 ; \mathrm{CI}[0.26,0.61])$. Therefore, resistance to change influences purchase intention both directly and indirectly through the willingness to pay. Similarly, for the relationship between the need for uniqueness and purchase intention, the indirect effect through the willingness to pay was significant $(b=0.18, p=0.04<0.05 ; \mathrm{CI}[0.1,0.26])$. The direct effect was then also significant $(b=0.18, p=0.0002<0.001 ; \mathrm{CI}[0.08,0]$.$) , signaling a partial mediation for this$ 
relationship. Likewise, for the link between perceived value and purchase intention, the indirect effect through willingness to pay was significant $(b=0.18, p=0.046<0.05$; $\mathrm{CI}[0.08,0.26])$. What is more, the direct effect was also significant $(b=0.53$, $p=0.000<0.001 ; \mathrm{CI}[0.40,0.67])$, indicating a partial mediation for this link. Therefore, resistance to change, need for uniqueness, and perceived value are all associated with purchase intention towards EVs.

Table 4: Results of Structural Model Analysis

\begin{tabular}{lccc}
\hline Hypotheses & Path & $\boldsymbol{f}^{2}$ & Result \\
\hline H1: WTP -> Purchase Intention & $0.18^{*}$ & 0.04 & Supported \\
H2a: RC -> WTP & $0.19^{*}$ & 0.04 & Supported \\
H2b: RC -> Purchase Intention & $0.18^{*}$ & 0.04 & Supported \\
H3a: UNIQ -> WTP & $0.13^{*}$ & 0.02 & Supported \\
H3b: UNIQ -> Purchase Intention & 0.08 & & Not supported \\
H4a: EC -> WTP & 0.16 & & Not supported \\
H4b: EC -> Purchase Intention & 0.01 & & Not supported \\
H5a: PT -> WTP & 0.11 & & Not supported \\
H5b: PT -> Purchase Intention & $0.18^{*}$ & 0.047 & Supported \\
H6: PN -> Purchase Intention & -0.08 & & Not supported \\
H7a: PV -> WTP & $0.27^{* * *}$ & 0.07 & Supported \\
H7b: PV -> Purchase Intention & $0.38^{* * *}$ & 0.16 & Supported \\
\hline$R^{2}$ for Purchase intention $0.595 * * *$ & & & \\
$R^{2}$ for WTP 0.459** & & & \\
$Q^{2}$ for Purchase intention 0.448 & & & \\
$Q^{2}$ for WTP 0.351 & & & \\
$*$ Significant at 0.05 level. & & & \\
$* *$ Significant at 0.01 level. & & & \\
$* * *$ Significant at 0.001 level. & & &
\end{tabular}

Figure 1: Evaluation of Structural Model

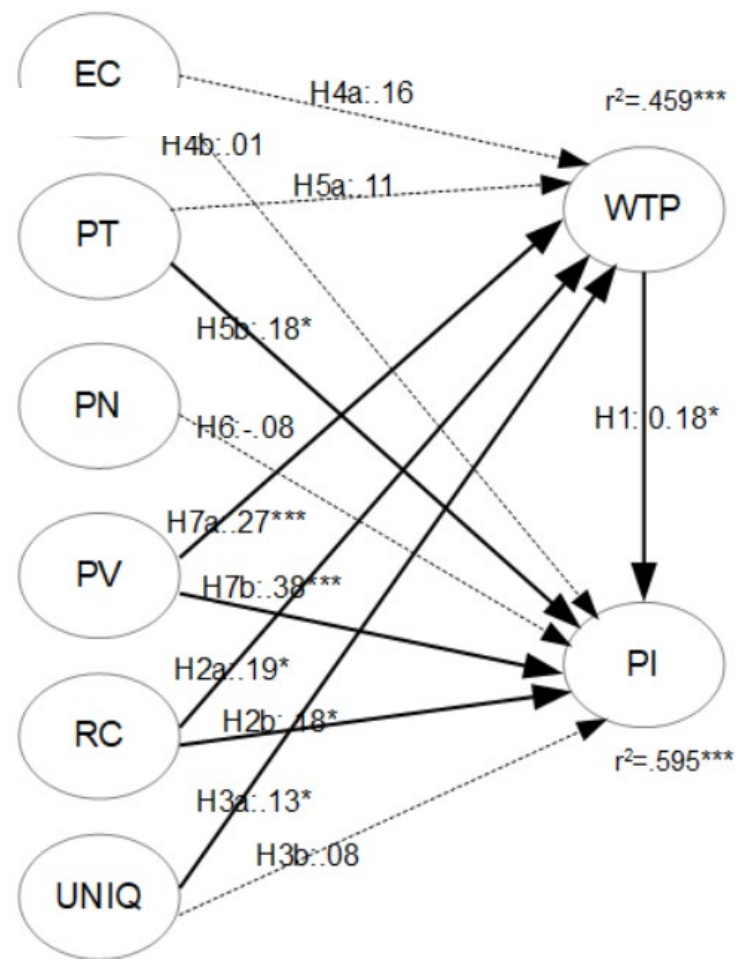




\section{Discussion and Implications}

A number of studies have been conducted in the area of EV adoption, nevertheless, scant attention has been paid to Southeast Asian countries, especially for Vietnam, the country possessing one of the most polluted cities in this Southeast Asia area (IQAir, 2018). Given that current studies lay heavy emphasis on developed and Western countries, more studies should be performed in Southeast Asian countries in light of different cultural values in these areas. Even among Southeast Asian countries, Vietnam is even a poorer country in which the GDP per capita of Vietnamese is considerably lower than that of other Southeast Asia contexts that previous studies have examined (e.g., Malaysia) (WorldBank, 2021a). This study was performed in Vietnam and therefore its results are able to enrich our understanding of the EV development path of this developing country. Besides, this study could help to throw support for policy makers and managers in Vietnam in increasing EV adoption.

This study incorporates two important psychological factors that were rarely examined in the EV adoption context, resistance to change and the need for uniqueness, into a comprehensive theoretical framework to explain the willingness to pay more and purchase intention of EVs. TPB model (Ajzen, 1991) and norm activation model (Bamberg and Möser, 2007; Manstead, 2000) were also used to explain proenvironmental behavior and intention (Bamberg and Möser, 2007). In doing so, the psychological determinants including self-interest and pro-social stimuli can be identified and evaluated (Bamberg and Möser, 2007). The results illustrated that resistance to change and the need for uniqueness have significant effects on willingness to pay more for EVs. In addition, resistance to change produces both direct and indirect effects on purchase intention for EVs whilst the need for uniqueness exerts indirect effects on purchase intention for EVs.

First, resistance to change was found to have significant positive effects on both the willingness to pay and purchase intention of EVs. Though these relationships were examined for some other industries such as Internet shopping or online banking, the marked effects of resistance to change on the willingness to pay more for EVs and purchase intention of EVs were little explored by past research. This study, therefore, makes an important contribution to the body of literature by indicating that resistance to change has an essential role to play in the willingness to pay more and purchase intention of EVs. As such, marketing efforts should aim to underscore the additional values (e.g., attractive monetary value and other services provided (Smith and Brynjolfsson, 2001) that could encourage consumers to change and accept EVs. In addition, the information with respect to the comfort and convenience of EVs should also be highlighted and conveyed to consumers. Furthermore, the government is in a position to shape deliberate policies aiming to encourage consumers to change from ICEVs to EVs. Such government policies could be government subsidies for EV purchases, tax and fee exemption (Kumar and Alok, 2020), highway lane excess, free parking policy, or toll tax exemption (Bjerkan et al., 2016). In fact, the Vietnamese government still provides limited national policies (Schröder and Iwasaki, 2021) that could assist Vietnamese consumers in adopting EVs.

Second, the need for uniqueness was found to have significant direct effects on willingness to pay and a significant indirect effect on purchase intention of EVs. Though similar findings can be found for some other products such as Coca-Cola (e.g., 
Netemeyer et al., 2004), however, the full effects of the need for uniqueness on the willingness to pay more for EVs and purchase intention of EVs were rarely examined in previous studies. On this basis, firms are encouraged to facilitate the creation of unique features and advertise these unique features widely to attract those people who need a sense of uniqueness. In the meantime, the adoption rate of EVs in Vietnam is very low, suggesting that the need for uniqueness is likely to be significantly related to the willingness to pay more and purchase intention. In doing so, these early adopters are likely to purchase EVs and become leaders, attracting followers (Fisher and Price, 1992). Thus, EV manufacturing firms should create special packages comprising a wide range of special services to attract these pioneers.

Third, the construct of perceived value was found to have the most significant positive effects on both the willingness to pay more for EVs and the purchase intention of EVs. This finding is consistent with past studies (e.g., Zhao et al., 2018). As such, marketing efforts should aim to underline such substantial benefits of EVs as less maintenance, distinctive styles, and the reasonable comfort of using EVs (Egbue and Long, 2012). In addition, such continuous improvements creating additional features that bring more value to consumers would be warranted (Schuitema et al., 2013). Fourth, perceived trust was found to be significantly related to the purchase intention of EVs. Hence, marketing efforts should emphasize environmental benefits of EVs in detail. For instance, EV manufacturing firms should invite environmental experts to present the environmental impacts of EVs.

\section{Limitations and Further Studies}

This study has some limitations that future studies can tackle. First, further research could repeat the study in other contexts of Southeast Asian countries to increase the generalizability of the findings. Second, in such developing countries as Vietnam, the presence of EVs is still limited and the knowledge of firms and consumers on EVs is still incomplete. This can create a promising avenue for further research on EVs and related concepts in the management and marketing field in this country.

\section{Practical Implications for Asian Business}

This study makes a significant contribution to the body of literature and provides practical implications for Asian business. Except for some developed Asian countries such as South Korea, New Zealand, or China, other developing Asian countries, for instance, Vietnam and Indonesia normally have low EV adoption rates (Statista, 2021b; Thuy, 2021) and severe environmental problems (IQAir, 2018). This study puts forwards real solutions to address these burning issues. First, Asian EV manufacturing firms are encouraged to put increased emphasis on how to reduce the resistance to change of customers. In doing so, customers are more likely to change from ICEVs to EVs. The primary focus should be on the ease and convenience to use EVs; the low switching costs; and the appealing features and styles of EVs. Second, the need for uniqueness is also of importance to increase the EV adoption rate. Accordingly, Asian manufacturing firms should shift the focus onto continuous improvements with unique features and creative styles created. These unique features, together with other functional values, are able to help considerably increase the purchase rate of EVs in 
developing Asian countries. Especially, communication and advertising are of utmost importance to deliver the highlighted messages to consumers, given that customer knowledge on EVs is normally incomplete. Having thorough knowledge of EVs, customers are more likely to increase their trust in EVs in terms of their great environmental value. This in turn leads to greater purchase intention and purchase behavior for EVs of customers.

Besides the implications for EV manufacturing firms in Asia, this study also offers some suggestions for policymakers. Accordingly, national policies established by Asian governments are also essential to encourage consumers to begin adopting EVs. A notable example is from Vietnam. Whilst such official policies as purchasing subsidies, the abolishment of quota policies, and tax exemption (Huang and Ge, 2019) could rapidly increase the sales of EVs (e.g., China) (CAAM, 2018), few official incentive policies for EVs were shaped by the Vietnamese government (Schröder and Iwasaki, 2021). In addition, the infrastructure for EVs in Vietnam is underdeveloped in which charging stations and service stations for EVs were only built in three provinces, Hanoi, Da Nang, and Quang Nam (Schröder and Iwasaki, 2021). Due to the limited infrastructure for EVs in Vietnam, local Vietnamese EV manufacturing firms such as Vingroup intended to launch from 30,000 to 50,000 completely new charging stations to serve their own EVs (Schröder and Iwasaki, 2021). Taken together, introducing coherent policies and developing basic infrastructure for EVs also have a vital role to play in increasing EV purchasing rates and reducing thorny environmental problems in developing Asian countries.

\section{References}

Ajzen, I. (1991), "The theory of planned behavior", Organizational behavior and human decision processes, vol. 50, no. 2, pp. 179-211.

Ajzen, I. (2005), “Attitudes, personality, and behavior”, McGraw-Hill Education, UK.

Al-Somali, S. A., Gholami, R. and Clegg, B. (2009), "An investigation into the acceptance of online banking in Saudi Arabia" Technovation, vol. 29, no. 2, pp. 130-141.

Asean Securities (2020), "Báo cáo phân tích ngành ô tô năm 2020", Retrieved 18/05/2021, from https://finance.vietstock.vn/bao-cao-phan-tich/6844/bao-cao-phan-tich-nganh-o-tonam-2020.htm.

Bamberg, S. and Möser, G. (2007), "Twenty years after Hines, Hungerford, and Tomera: A new meta-analysis of psycho-social determinants of pro-environmental behavior", Journal of environmental psychology, vol. 27, no. 1, pp. 14-25.

Bang, H. K., Ellinger, A. E., Hadjimarcou, J. and Traichal, P. A. (2000), "Consumer concern, knowledge, belief, and attitude toward renewable energy: An application of the reasoned action theory", Psychology \& Marketing, vol. 17, no. 6, pp. 449-468.

Bartikowski, B. and Cleveland, M. (2017), "“Seeing is being": Consumer culture and the positioning of premium cars in China", Journal of Business Research, vol. 77, pp. 195202.

Belk, R. W. (1988), "Possessions and the Extended Self”, Journal of Consumer Research, vol. 15 , no. 2, pp.139-168.

Bendapudi, N. and Berry, L. L. (1997), "Customers' motivations for maintaining relationships with service providers", Journal of retailing, vol. 73, no. 1, pp. 15-37.

Bjerkan, K. Y., Nørbech, T. E. and Nordtømme, M. E. (2016), "Incentives for promoting battery electric vehicle (BEV) adoption in Norway", Transportation Research Part D: Transport and Environment, vol. 43, pp. 169-180.

Bohnsack, R., Pinkse, J. and Kolk, A. (2014) "Business models for sustainable technologies: 
Exploring business model evolution in the case of electric vehicles", Research Policy, vol. 43, no. 2, pp. 284-300.

BVSC (2021), "Báo cáo cập nhật ngành ô tô 02.2021" Retrieved 08/05/2021, from https://bvsc.com.vn/Reports/8343/bao-cao-cap-nhat-nganh-o-to-02-2021-trien-vongcho-o-to-va-xe-may-tot-hon-nhieu.aspx

CAAM (China Association of Automobile Manufacturers) (2018), Retrieved 07/06/2021, from Automotive Industry Economic Operation. http://www.caam.org.cn/.

Chang, T. Z. and Wildt, A. R. (1994), "Price, product information, and purchase intention: An empirical study", Journal of the Academy of Marketing science, vol. 22, no. 1, pp. 1627.

Chen, Y.S., Lin, C.Y. and Weng, C.S. (2015), "The Influence of environmental friendliness on green trust: The mediation effects of green satisfaction and green perceived quality", Sustainability, vol. 7, pp. 10135-10152.

Chin, W. W. (1998), "Commentary: Issues and opinion on structural equation modeling", JSTOR.

Cohen, J. (1988), Statistical power analysis for the behavioral sciences (2nd ed.), Hillsdale, N.J: Lawrence Erlbaum Associates.

Daniel, E. (1999), "Provision of electronic banking in the UK and the Republic of Ireland", International Journal of Bank Marketing, vol. 17, no. 2, pp. 72-82.

Dylan Pastoor (2018), "Vinfast and the Electric Vehicle Market in Vietnam"

Egbue, O. and Long, S., (2012), "Barriers to widespread adoption of electric vehicles: An analysis of consumer attitudes and perceptions", Energy Policy, vol. 48, pp. 717-729.

Essoussi, L. H. and Zahaf, M. (2008), "Decision making process of community organic food consumers: an exploratory study", Journal of Consumer Marketing, vol. 25, no. 2, pp. 95-104.

Fisher, R. J. and Price L. L. (1992), "An Investigation into the Social Context of Early Adoption Behavior", Journal of Consumer Research, vol. 19, no. 3, pp.477-486.

Fornell, C. and Larcker, D. F. (1981), "Evaluating structural equation models with unobservable variables and measurement error", Journal of marketing research, vol. 18, no. 1, pp. 39-50.

Garson, G. D. (2016), Partial Least Squares: Regression and Structural Equation Models, Statistical Associates Publishers, Asheboro, NC.

Hair, J. F., Hult, G. T. M., Ringle, C. and Sarstedt, M. (2014), A primer on partial least squares structural equation modeling (PLS-SEM), Sage publications, Thousand Oaks.

Hair, J. F., Ringle, C. M. and Sarstedt, M. (2011), "PLS-SEM: Indeed a silver bullet", Journal of Marketing theory and Practice, vol. 19, no. 2, pp. 139-152.

Han, L., Wang, S., Zhao, D. and Li, J. (2017), "The intention to adopt electric vehicles: Driven by functional and non-functional values", Transportation Research Part A: Policy and Practice, vol. 103, pp. 185-197.

Hansla, A., Gamble, A., Juliusson, A. and Gärling, T. (2008), "Psychological determinants of attitude towards and willingness to pay for green electricity", Energy policy, vol. 36, no. 2, pp. 768-774.

He, X., Zhan, W. and Hu, Y. (2018), "Consumer purchase intention of electric vehicles in China: The roles of perception and personality", Journal of Cleaner Production, vol. 204, pp. 1060-1069.

Henseler, J., Ringle, C.M. and Sarstedt M. (2015), "A new criterion for assessing discriminant validity in variance-based structural equation modeling", Journal of the academy of marketing science, vol. 43, no. 1, pp. 115-135.

Hofmann, J., Guan, D., Chalvatzis, K. and Huo, H. (2016), “Assessment of electrical vehicles as a successful driver for reducing CO2 emissions in China", Applied energy, vol. 184, pp. 995-1003.

Huang, X. and Ge, J. (2019), "Electric vehicle development in Beijing: An analysis of consumer purchase intention", Journal of cleaner production, vol. 216, pp. 361-372.

IQAir (2018), "2018 World Air Quality Report”, Retrieved 08/05/2021, from https:/www.iqair.com/blog/press-releases/IQAir-AirVisual-2018-World-Air-Quality- 
Report-Reveals-Worlds-Most-Polluted-Cities

Jones, L. R., Cherry, C. R., Vu, T. A. and Nguyen, Q. N. (2013), "The effect of incentives and technology on the adoption of electric motorcycles: A stated choice experiment in Vietnam", Transportation Research Part A: Policy and Practice, vol. 57, pp. 1-11.

Ju, Y., Ju, D., Gonzalez, E. D. S., Giannakis, M. and Wang, A. (2019), "Study of site selection of electric vehicle charging station based on extended GRP method under picture fuzzy environment", Computers \& Industrial Engineering, vol. 135, pp. 1271-1285.

Kahn, M. E. (2007), "Do greens drive Hummers or hybrids? Environmental ideology as a determinant of consumer choice", Journal of Environmental Economics and Management, vol. 54, no. 2, pp. 129-145.

Kalra, A. and Goodstein, R. C. (1998), "The impact of advertising positioning strategies on consumer price sensitivity", Journal of Marketing Research, vol. 35, no. 2, pp. 210224.

Kang, M. J. and Park, H. (2011), "Impact of experience on government policy toward acceptance of hydrogen fuel cell vehicles in Korea", Energy policy, vol. 39, no. 6, pp. 3465-3475.

Kim, H. W. and Gupta, S. (2012), "Investigating Customer Resistance to Change in Transaction Relationship with an Internet Vendor", Psychology and Marketing, vol. 29, no. 4, pp. 257-269.

Kron, J. (1983), Home-Psych: The Social Psychology of Home and Decoration, Potter, New York.

Kumar, R. R. and Alok, K. (2020), "Adoption of electric vehicle: A literature review and prospects for sustainability", Journal of Cleaner Production, vol. 253, pp. 119911.

Lai, I. K., Liu, Y., Sun, X., Zhang, H. and Xu, W. (2015), "Factors influencing the behavioural intention towards full electric vehicles: An empirical study in Macau", Sustainability, vol. 7, no. 9, pp. 12564-12585.

Le, T. T., Nguyen, T. L., Trinh, M. T., Le, V. T. and Pham, H. H. (2021), "Investigating Vietnamese undergraduate students' willingness to pay for higher education under the cost-sharing context", Policy Futures in Education, pp. 14782103211011898.

Lee, K., (2009), "Gender differences in Hong Kong adolescent consumers' green purchasing behavior”, Journal of Consumer Marketing, vol. 26, no. 2, pp. 87-96.

Lee, Y. K., Kim, S., Kim, M. S. and Choi, J. G. (2014), “Antecedents and interrelationships of three types of pro-environmental behavior", Journal of Business Research, vol. 67, no. 10, pp. 2097-2105.

Liu, Y., Ouyang, Z. and Cheng, P. (2019), "Predicting consumers' adoption of electric vehicles during the city smog crisis: An application of the protective action decision model", Journal of Environmental Psychology, vol. 64, pp. 30-38.

Malhotra, N. (2006), Marketing research: an applied orientation (3rd [Australian] ed.), Pearson/Prentice Hall, Frenchs Forest, N.S.W.

Manstead, A. S. R. (2000), "The role of moral norm in the attitude-behaviour relation", In D.J. Terry, \& M. A. Hogg (Eds.), Attitude, behaviour, and social context. The role of norms and group membership, pp. 11-30, Lawrence Erlbaum, Mahwah, NY.

McAlister, L. and Pessemier, E. (1982), "Variety Seeking Behavior: An Interdisciplinary Review", Journal of Consumer Research, vol. 9, no. 3, pp. 311-322.

Milfont, T. L. and Gouveia, V. V. (2006), "Time perspective and values: An exploratory study of their relations to environmental attitudes", Journal of environmental psychology, vol. 26, no. 1, pp. 72-82.

Minh, N. K. (2020), "Features and prospects of the electric vehicle in the Vietnamese automobile market", In IOP Conference Series: Materials Science and Engineering, vol. 819, no. 1, pp. 012007, IOP Publishing.

Moser, A.K., (2015), "Thinking green, buying green? Drivers of pro-environmental purchasing Behavior", Journal of Consumer Marketing, vol. 32, no. 3, pp. 167-175.

Munir, S., Humayon, A. A., Ahmed, M., Haider, S. and Jehan, N. (2017), "Brand image and customers' willingness to pay a price premium for female's stitched clothing", Pakistan Journal of Commerce and Social Sciences (PJCSS), vol. 11, no. 3, pp. 1027-1049. 
National Assessment Synthesis Team (2000), Climate Change Impacts on the United States: The Potential Consequences of Climate Variability and Change, US Global Change Research Program, Washington, D.C.

Nayum, A., Klöckner, C. A. and Mehmetoglu, M. (2016), "Comparison of socio-psychological characteristics of conventional and battery electric car buyers", Travel Behaviour and Society, vol. 3, pp. 8-20.

Netemeyer, R.G., Krishnan, B., Pullig, C., Wang, G., Yagci, M., Dean, D., Ricks, J. and Wirth, F. (2004), "Developing and validating measures of facets of customer-based brand equity", Journal of Business Research, vol. 57, no. 2, pp. 209-224.

Ng, M., Law, M. and Zhang, S. (2018), "Predicting purchase intention of electric vehicles in Hong Kong”, Australasian Marketing Journal (AMJ), vol. 26, no. 3, pp. 272-280.

Nunnally, J. C. (1978), Psychometric theory (2nd ed.), McGraw-Hill, Hillsdale, NJ.

Olson, E. L. (2013), "It's not easy being green: the effects of attribute tradeoffs on green product preference and choice", Journal of the Academy of Marketing Science, vol. 41, no. 2, pp. 171-184.

Oreg, S. (2003), "Resistance to change: Developing an individual differences measure", Journal of applied psychology, vol. 88, no. 4, pp. 680.

Paul, J. and Rana, J. (2012), "Consumer behavior and purchase intention for organic food", Journal of consumer Marketing, vol. 29, no. 6, pp. 412-422.

Pavlou, P. A. (2003), "Consumer acceptance of electronic commerce: Integrating trust and risk with the technology acceptance model", International journal of electronic commerce, vol. 7, no. 3, pp. 101-134.

Peters, A., Gutscher, H. and Scholz, R. W. (2011), "Psychological determinants of fuel consumption of purchased new cars", Transportation Research Part F: Traffic Psychology and Behaviour, vol. 14, no. 3, pp. 229-239.

Preacher, K. J., and Hayes A. F. (2008), "Asymptotic and resampling strategies for assessing and comparing indirect effects in multiple mediator models", Behavior research methods, vol. 40, no. 3, pp. 879-891.

Quinn, R.B. and Mueller, J.A. (1982), "Transferring research results to operations", in Tushman and Moore (Eds), Readings in the Management of Innovation, Pitman, MA, pp. 62.

Reviewxehoi360 (2019), Top 6 diễn đàn xe hơi lớn nhất Việt Nam, Retrieved 23/08/2021 from http://reviewxehoi360.com/top-6-dien-dan-o-to-lon-nhat-o-viet-nam/

Rezvani, Z., Jansson, J. and Bodin, J. (2015), "Advances in consumer electric vehicle adoption research: A review and research agenda", Transportation research part D: transport and environment, vol. 34, pp. 122-136.

Ringle, C. M., Wende, S. and Becker J.-M. (2015), SmartPLS 3. Boenningstedt: SmartPLS GmbH. http://www.smartpls.com.

Rivis, A., Abraham, C. and Snook, S. (2015), "Understanding young and older male drivers' willingness to drive while intoxicated: The predictive utility of constructs specified by the theory of planned behaviour and the prototype willingness model", British journal of health psychology, vol. 16, no. 2, pp. 445-456.

Samuelson, W. and Zeckhauser, R. (1988), "Status quo bias in decision making", Journal of risk and uncertainty, vol. 1, no. 1, pp. 7-59.

Sang, Y. N. and Bekhet, H. A. (2015), "Exploring factors influencing electric vehicle usage intention: an empirical study in Malaysia", International Journal of Business and Society, vol. 16, no. 1.

Sarstedt, M., Ringle, C. M. and Hair, J. F. (2017), "Partial Least Squares Structural Equation Modeling", Handbook of Market Research, vol. 26. no. 1, pp. 1-40.

Schröder, M. and Iwasaki F. (2021), "Current Situation of Electric Vehicles in ASEAN", in Schröder, M., Iwasaki F. and Kobayashi, H. (eds.) Promotion of Electromobility in ASEAN: States, Carmakers, and International Production Networks. ERIA Research Project Report FY2021 no.03, Jakarta: ERIA, pp.1-32.

Schuitema, G., Anable, J., Skippon, S. and Kinnear, N. (2013), "The role of instrumental, hedonic and symbolic attributes in the intention to adopt electric 
vehicles", Transportation Research Part A: Policy and Practice, vol. 48, pp. 39-49.

Schwartz, S. H. (1977), "Normative influences on altruism", In Advances in experimental social psychology 10, pp. 221-279. Academic Press.

Scown, C. D., Taptich, M., Horvath, A., McKone, T. E. and Nazaroff, W. W. (2013), "Achieving deep cuts in the carbon intensity of US automobile transportation by 2050: complementary roles for electricity and biofuels", Environmental science \& technology, vol. 47, no. 16, pp. 9044-9052.

Sheppard, B. H., Hartwick, J. and Warshaw, P. R. (1988), "The theory of reasoned action: A meta-analysis of past research with recommendations for modifications and future research", Journal of consumer research, vol. 15, no. 3, pp. 325-343.

Sheth, J. N. (1983), "Integrative theory of patronage and behavior, in patronage behavior and retail management", New York, North-Holland, elserier Science Publishing Company, Inc.

Shi, X., Wang, X., Yang, J. and Sun, Z. (2016), "Electric vehicle transformation in Beijing and the comparative eco-environmental impacts: A case study of electric and gasoline powered taxis", Journal of Cleaner Production, vol. 137, pp.449-460.

Smith, M. and Brynjolfsson, E. (2001), "Customer decision making at an Internet shopbot: Brand still matters", The Journal of Industrial Economics, vol. 49, pp. 541-558.

Statista (2021a), "ASEAN countries: Gross domestic product (GDP) per capita in current prices from 2010 to 2020", Retrieved 10/06/2021, from https://www.statista.com/statistics/804307/gross-domestic-product-gdp-per-capita-inthe-asean-countries/

Statista (2021b), "Market share of electric cars (EV) in Asia Pacific in 2020, by country". Retrieved 08/07/2021, from https://www.statista.com/statistics/1107877/apac-evmarket-share-by-country/

Thuy, T. (2021), "Vừa đi vừa lo ô tô điện khi nào bùng nổ", Retrieved 08/05/2021, from https://vietnamnet.vn/vn/kinh-doanh/dau-tu/vua-di-vua-lo-o-to-dien-khi-nao-bungno-710186.html

Thuy, T. T., \& Hong, P. T. T. (2019), "Attitude to and usage intention of high school students toward electric two-wheeled vehicles in Hanoi City", VNU Journal of Science: Economics and Business, vol. 35, no. 2, pp. 47-62.

Tian, K. T., Bearden, W. O. and Hunter, G. L. (2001), “Consumers' need for uniqueness: Scale development and validation", Journal of Consumer Research, vol. 28, no. 1, pp. 5066.

Tuyen, N. (2021), "Các nước ồ ạt ưu đãi chính sách xe điện Việt vẫn đơn thương độc mã”, Retrieved 08/05/2021, from https://timhieuvietnam.vn/cac-nuoc-o-at-uu-dai-chinhsach-xe-dien-viet-van-don-thuong-doc-ma

Wallis Report (1997), The Financial System Inquiry Final Report (Chairman: Mr Stan Wallis), AGPS, Canberra.

Wang, S., Fan, J., Zhao, D., Yang, S. and Fu, Y. (2016), "Predicting consumers' intention to adopt hybrid electric vehicles: using an extended version of the theory of planned behavior model", Transportation, vol. 43, no. 1, pp. 123- 143.

Wei, W., Cao, M., Jiang, Q., Ou, S. J. and Zou, H. (2020), "What Influences Chinese Consumers' Adoption of Battery Electric Vehicles? A Preliminary Study Based on Factor Analysis", Energies, vol. 13, no. 5, pp. 1057.

Wold, H. (1982), "Soft modeling: the basic design and some extensions", Systems under indirect observation, vol. 2, pp. 343.

WorldBank (2021a), “GDP per capita (current US\$) - Vietnam”, Retrieved 14/06/2021, from https://data.worldbank.org/indicator/NY.GDP.PCAP.CD?locations $=\mathrm{VN}$

WorldBank (2021b), "Vietnam overview", Retrieved 23/08/2021, from https://www.worldbank.org/en/country/vietnam/overview.

$\mathrm{Wu}, \mathrm{W}$. Y. and Ke, C. C. (2015), "An online shopping behavior model integrating personality traits, perceived risk, and technology acceptance", Social Behavior and Personality: An International Journal, vol. 43, no. 1, pp. 85-97.

Yang, H., Yu, J., Zo, H. and Choi, M. (2016), "User acceptance of wearable devices: An 
extended perspective of perceived value", Telematics and Informatics, vol. 33, no. 2, pp. 256-269.

Zhang, Y., Yu, Y. and Zou, B. (2011), "Analyzing public awareness and acceptance of alternative fuel vehicles in China: The case of EV", Energy Policy, vol. 39, no. 11, pp. 7015-7024.

Zhao, R., Geng, Y., Liu, Y., Tao, X. and Xue, B. (2018), “Consumers' perception, purchase intention, and willingness to pay for carbon-labeled products: A case study of Chengdu in China", Journal of Cleaner Production, vol. 171, pp. 1664-1671. 